\title{
Commentary on Award on Jurisdiction and Admissibility of the Philippines-instituted Arbitration under Annex VII to the UNCLOS: A Discussion on Fact-Finding and Evidence
}

\author{
He Tiantian \\ Assistant Professor, Institute of International Law, Chinese Academy of Social \\ Science, China \\ hetiantian@cass.org.cn
}

\begin{abstract}
The Arbitral Tribunal in the arbitration instituted by the Philippines against China has issued its Award on Jurisdiction and Admissibility. Juridical practices have something in common. The arbitral proceedings generally comprise two indispensable stages: findings of fact and application of law. The production, collection, and evaluation of evidence serve a particular purpose: they are meant to enable the adjudicative body to find facts. Thus, evidence is meant to prove or disprove facts. This review paper aims to discuss evidence and fact-finding process in the Award. As a general rule, international judges or arbitrators have wide discretion in the evaluation of evidence, but the guiding principle of the rules governing evidence should be the principle of fair trial. The problems of evidence evaluation and fact-finding revealed in the Award would be much serious at the merits stage, thus have negative implications for the Tribunal to deliver its decision impartially.
\end{abstract}

* The author would like to thank the anonymous reviewers for their comments and for the editorial team of this journal for polishing the article. Of course, the responsibility is the author's for any mistakes and errors. The author wishes to declare that the viewpoints in the article are hers and do not necessarily represent those of any institution or those of the Chinese government. 


\section{Keywords}

United Nations Convention on the Law of the Sea - South China Sea - Compulsory procedure - Fact-finding - Evidence

On 29 October 2015, the Arbitral Tribunal constituted under Annex VII to the United Nations Convention on the Law of the Sea ( the "Convention") ${ }^{1}$ in the arbitration instituted by the Republic of the Philippines against the People's Republic of China rendered its Award on Jurisdiction and Admissibility. This Award was unanimous and concerns only whether the Tribunal has jurisdiction to consider the Philippines' claims and whether such claims are admissible. It was given on the fact that the Arbitral Tribunal has decided in its fourth Procedural Order that it will treat China's communications (including the Position Paper $)^{2}$ as constituting a plea concerning the Arbitral Tribunal's jurisdiction. The Tribunal concluded that it does have jurisdiction with respect to the matters raised in seven of the Philippines' claims. ${ }^{3}$ The Chinese Foreign Ministry released a statement on 30 October 2015, expressing its position that this Award is null and void, and that it has no binding effect on China. ${ }^{4}$ As

1 United Nations Convention on the Law of the Sea (done 10 December 1982, entry into force 16 November 1994), 1833 UNTS 3, [hereinafter referred to as UNCLOS or the Convention]. Articles cited without particular references are those of the Convention.

2 On 7 December 2014, China officially published its Position Paper "on the Matter of Jurisdiction in the South China Sea Arbitration initiated by the Republic of the Philippines" [hereafter, "Position Paper"]. Position Paper is available at the website of the Foreign Ministry of China, http://www.fmprc.gov.cn/mfa_eng/zxxx_662805/t1217147.shtml (last visited on 3 February 2016).

3 An Arbitral Tribunal Constituted under Annex VII to the 1982 United Nations Convention on the Law of the Sea (Philippines/China), Award on Jurisdiction and Admissibility [hereinafter refers to as "Award"], para. 413; also see Ninth Press Release 30112015, available at the website of Permanent Court of Arbitration, http://www.pcacases.com/web/view/7 (last visited on 3 February 2016).

4 "Statement of the Ministry of Foreign Affairs of the People's Republic of China on the Award on Jurisdiction and Admissibility of the South China Sea Arbitration by the Arbitral Tribunal Established at the Request of the Republic of the Philippines", available at the website of Foreign Ministry of China, http://www.fmprc.gov.cn/mfa_eng/zxxx_662805/t1310474.shtml (last visited on 3 February 2016). 
for the present arbitration, the Chinese Government has subsequently reiterated that it will neither accept nor participate in the arbitration thus initiated by the Philippines. Many scholars, both inside and outside China, have expressed the view that the Tribunal has no jurisdiction on the claims brought by the Philippines. ${ }^{5}$

The reasoning of the tribunal's award can be summarized from paragraphs 398 to 410 of the Award, as follows:

First, the Tribunal held that "the States Parties to the Convention are accordingly not free to pick and choose the portions of the Convention they wish to accept or reject." ${ }^{\prime}$ That is, once are the state parties of the Convention, countries are deemed to have accepted the dispute settlement procedures in the Convention, according to Article $286 .{ }^{7}$

\section{Article 286}

\section{Application of procedures under this section}

Subject to section 3, any dispute concerning the interpretation or application of this Convention shall, where no settlement has been reached by recourse to section 1, be submitted at the request of any party to the dispute to the court or tribunal having jurisdiction under this section.

Second, the Tribunal needs to determine the existence of a dispute and that the dispute concerns the interpretation or application of the Convention between the Parties in accordance with Article $288 .{ }^{8}$

Further, after an affirmative reply to whether the dispute exists, the Tribunal must be satisfied that no settlement has been reached by recourse to other peaceful means of dispute settlement as contemplated in Section 1 of Part XV of the Convention. In addition, the Tribunal must be satisfied that none of

5 For references and discussion see Song Yann-huei, The South China Sea Arbitration Case Filed by the Philippines against China: A Discussion on Preliminary Objections to the Tribunal's Jurisdiction, 2 Chinese Review of International Law (2014), at pp. 5-32; Stefan Talmon and Bing Bing Jia (eds), The South China Sea Arbitration: A Chinese Perspective (Oxford: Hart Publishing 2014); Shicun Wu, Keyuan Zou, Arbitration Concerning the South China Sea: Philippines versus China (Routledge, 2016).

6 Award, para. 107, para. 358, "The Tribunal has already held that the Convention does not permit a state party to exempt itself generally from the dispute settlement provisions of Part XV and that no consequences for the Tribunal's jurisdiction follow from China's decision not to participate in these proceedings."

7 Award, paras. 108-111.

8 This step corresponds to Part v. Identification and Characterisation of the Dispute in the Award. 
the specific limitations and exceptions set out in Section 3 of Part XV of the Convention applies. ${ }^{9}$

Fourth, with no limitations and exceptions to the Tribunal's jurisdiction, the Tribunal concluded that there were no factors to hamper its jurisdiction and thus it has jurisdiction over certain of claims that have "exclusively preliminary character".

It is worth noting that the Tribunal's reasoning is based on the premise that the dispute settlement procedures of the Convention were reasonably interpreted. However, for a tribunal, merely having a good logic starting point is not sufficient. It is equally important and relevant how the tribunal reaches the conclusion. The judicial or arbitral proceedings generally comprise two indispensable stages: findings of fact and application of law. It is true that without findings of fact that generally accord with truth, the law could not be applied legitimately and fairly. The Tribunal's application of law must be based on accurate fact-finding. Fact-finding is a process whereby an adjudicative body investigates a matter to determine the disputed fact before applying existing law. Fundamentally speaking, the production, collection, and evaluation of evidence serve a particular purpose: they are meant to enable the adjudicative body to find facts. Consequently, evidence is meant to prove or disprove facts and it plays an important role in legal practice. This paper aims to discuss the Award from a fact-finding (evidence) perspective, which reflects clearly what the arbitrators concerned and what is produced by their contemplation and reasoning.

The article is structured as follows. Section 2 discusses the general problems of fact-finding (evidence) in the Award, with the same logic staring point as the Tribunal had. Section 3 discusses the specific problems of fact-finding and evidence in the process of the Tribunal identifying the dispute concerning the interpretation or application of the Convention. Section 4 examines the issues of fact-finding and evidence in the Tribunal's reasoning on the precondition to the jurisdiction. ${ }^{10}$ Section 5 examines the possible difficulties of fact-finding

This step corresponds to Part VII. Preconditions to the Tribunal's Jurisdiction and Part VIII Limitations and Exceptions to the Tribunal's Jurisdiction in the Award: also see Award, para. 110, it stated that "Further, as stated in Article 286, the Tribunal must be satisfied that no settlement has been reached by recourse to other peaceful means of dispute settlement as contemplated in Section 1 of Part Xv. Additionally, the Tribunal must be satisfied that none of the specific limitations and exceptions set out in Section 3 of Part XV of the Convention apply."

10 Section 3 of this article only presents an analysis of "where no settlement has been reached by recourse to section 1" provided in Article 286, namely the precondition to the Tribunal's jurisdiction. The reason for not discussing "Subject to section 3 " is the Tribunal 
on the merits by the Tribunal. The Conclusion, Section 6, points out the implications of the author's findings.

The existence of jurisdiction of the adjudicative body in a given case is "a question of law to be resolved in the light of the relevant facts".11 Pursuant to Article 9 of Annex VII to the Convention and Article 25.1 of the Rules of Procedure, the Arbitral Tribunal must satisfy itself not only that it has jurisdiction over the dispute but also that the claim is well founded in fact and law before rendering its award. ${ }^{12}$ The word "well founded in fact and law" also appears in Article 53(2) of the Statute of International Law of Justice, which also points out that the judicial body shall make a sound decision whenever one of the parties does not appear before the Court.

However, there is neither precise or uniform definition nor relevant rules in international law on what is "well founded in fact". ${ }^{13}$ In Corfu Chanel Case, the ICJ held that "it is sufficient for the court to convince itself by such methods as it considers suitable that the submissions are well founded". ${ }^{14}$ That an adjudicative body, whether an arbitral tribunal or a court, verifies the fact on sound basis is a crucial step in a legal proceeding. Fact-Finding is the basis of application of law; work on evidence is the core in the process of fact-finding.

concluded that Submissions concerning the limitations and exceptions (Article 197 and 298) have no preliminary character, which should decide on the merits. Also see Award, paras. $380-383$.

Border and Trans-border Armed Actions (Nicaragua v. Honduras), [1988] ICJ Reports, p. 76, para. 16.

12 On 27 August 2013, the Tribunal issued its first Procedural Order, establishing the initial timetable for the arbitration and adopting Rules of Procedure. Rules of Procedure is available at the website of the Permanent Court of Arbitration, http://www.pcacases .com/web/view/7 (last visited on 3 February 2016); Article 25(1) of Rules of Procedure provides that "1.... Before making its award, the Arbitral Tribunal must satisfy itself not only that it has jurisdiction over the dispute but also that the claim is well founded in fact and law"; also see Award, para. 39.

13 Andreas Zimmermann, Karin Oellers-Frahm, Christian Tomuschat, and Christian J. Tams, The Statute of the International Court of Justice: A Commentary (Oxford: Oxford University Press, 2nd edn, 2012), p. 1346.

14 Corfu Channel (United Kingdom of Great Britain and Northern Ireland v. Albania), Judgment, [1949 ] ICJ Reports, p. 248. Followed in the United States Diplomatic and Consular Staff in Tehran (United States of America v. Iran), [1980] ICJ Reports, pp. 3, 9, para. 11. 
Where does evidence come from? In international rules and legal practice, there are numerous measures that international tribunals may take to exercise their fact-finding power. The most common among these measures is the power of international tribunals to request the parties to furnish relevant documents and information at their disposal. ${ }^{15}$ Calling witnesses is also one of the means for fact-finding. Articles 22 and 24 of the Rules of Procedure provide relevant information on this. Referring to independent experts or expert panels appointed by the adjudicative body is another frequently used way for fact-finding in recent years. ${ }^{16}$ In addition, a pre-hearing conference, site visit and inquiry from third parties not involved in the case are also some factfinding measures. ${ }^{17}$ In practice, no matter which measure(s) the adjudicative body adopts, the arbitrators or judges have a wide discretion in dealing with evidence. The ICJ has freedom in estimating the value of the various elements of evidence within the limits of its Statute and Rules. ${ }^{18}$ It should be pointed out that, however, an arbitration tribunal should be distinguished from other international judicial courts by its more flexible feature in exercising its power, which is also reflected in Article 22(7) of the Rules of Procedure. It provides that, "The Arbitral Tribunal shall determine the admissibility, relevance, materiality, and weight of the evidence adduced."19

Fact-Finding process by international adjudicative body can be summarized in three categories: production of evidence; admission or rejection of evidence; and evaluation or interpretation of evidence. ${ }^{20}$ In the present case, some general problems lie in the fact-finding process in all three categories.

In the first place, as for the production of evidence, what kind of evidence the Tribunal can get depends on the willingness of the Parties. This is a fundamental difference between the international tribunals' fact-finding process and that of the national ones. In a national legal proceeding, a tribunal may

15 For references and discussion on documentary evidence see Shabtai Rosenne and Yaël Ronen, The Law and Practice of the International Court, 1920-2005, (Leiden: Martinus Nijhoff, 4th edn, 2006), pp. 1043-1052.

16 For references and discussion on expert witness see Shabtai Rosenne and Yaël Ronen, The Law And Practice Of The International Court, 1920-2005, pp. 1116-1119, 1137-1139, 1305-1320.

17 Chittharanjan F. Amerasinghe, Evidence in International Litigation (Leiden: Brill Academic Publisher, 2015), pp. 152-162.

18 Military and Paramilitary Activities in and against Nicaragua (Nicaragua v. United States of America), [1984 ] ICJ Reports, p. 418, para. 60.

19 Article 22(7) of Rule of Procedure provides that, "The Arbitral Tribunal shall determine the admissibility, relevance, materiality, and weight of the evidence adduced."

20 Paul S. Reichler, Problems of Evidence before International Tribunals, in John Norton Moore(ed.), International Arbitration: Contemporary Issues and Innovations, pp. 47-48. 
collect on its own evidence that it considers necessary. However, it is not the case for an international tribunal. That is to say, production of evidence before international courts or tribunals is voluntary; it is up to the parties to produce whatever evidence they consider useful to their claims. A party is not obliged to provide anything adverse to its claims to the adjudicative body. The phenomenon that a party will not produce some key documents or evidence that contradict its claims is rarely encountered, which means that such evidence is unlikely to come to the Tribunal's attention. Allowing the parties to produce evidence that only benefits themselves poses a challenge to the tribunal concerning the verification the facts. The counsel of the Philippines, Paul S. Reichler, is also well aware of the magnitude of the problem in one of his articles. In the article, he admitted that this is a serious problem not only for the court, but also for the whole concept of fairness in international adjudication. In his own words, "How can a court dispense justice if it is prevented from learning all of the key facts on which a just sentence or award depends?"21 As an experienced lawyer in international litigation, Paul S. Reichler knows well the relation between evidence, fact-finding and decision-making.

The problem is aggravated when one of the Parties does not appear in the proceeding. The Tribunal cannot understand sufficiently the arguments of the absent party, and its decision is made based only on the evidence provided unilaterally. Even worse, how can an adjudicative body know whether or not there are crucial facts that have been concealed by the present party? Ironically, "it not only cannot know about facts that are not presented to it, but it has no way of knowing whether there are facts that have not been presented to it."22 In such a situation, how can a tribunal make a decision well founded in fact and law? It is the very unknown facts that will perhaps play a crucial role in the Tribunal's final decision. Paul S. Reichler even suggested in his article that, in order to reduce the likelihood that the key evidence is withheld by the parties, international courts should adopt the American system of discovery. He also advocated that international courts should have the power of sufficient evidence production. ${ }^{23}$

In this present case, the Memorial of the Philippines consists of eleven volumes. Volume I comprises the main text of the Memorial, together with plenty of illustrative maps and figures. Volumes II to XI contain supporting materials. Including numerous figures, maps and nautical charts, Volume XI contains legal authorities. There are a large number of documentary files, figures, and

\footnotetext{
21 Ibid., p. 47.

22 Ibid., p. 47.

23 Ibid., p. $5^{2}$.
} 
maps that are used to justify Philippines' claims, totaled about 3,70o pages. ${ }^{24}$ The Philippines filed a supplemental written submission on 15 March 2015 addressing the Arbitral Tribunal's request, which contains enormous quantities of information. To speak without exaggeration, it is a hard task for the five arbitrators to access, interpret and evaluate this enormous amount of material in a limited period of time. The task was so complicated that nothing short of two present parties would be required.

Secondly, the Tribunal's power to collect and handle the evidence is limited. As suggested by Reichler, international courts or tribunals should fully exercise their power they already have through a more robust management of the evidence production process. Characteristics of arbitration, however, simply limit the exercise of this type of power. Arbitration is a means of dispute settlement that is milder and more reverent at Parties' will. Thus, the power of the Arbitrator is subject to the procedure rules and the Parties' willingness.

As far as the present case concerns, Article 22(2) of the Procedural Rule does not provide all the appropriate measures mentioned above for the Tribunal to establish facts, except "site visit". ${ }^{25}$ However, the Chinese Government has reiterate that it will neither accept nor participate in the arbitration, ${ }^{26}$ and China has expressed firm opposition to some of the procedural items raised in the rules, such as site visits. ${ }^{27}$ In the arbitration process, the two Parties themselves can select rules to advance the arbitration. To a certain extent, the willingness of the parties limits the power of the arbitral tribunal, which will ultimately influence the decision. Because of the absence of China, the fairness of the Award is being questioned.

Thirdly, international arbitrators have broad discretion in the assessment of evidence. The procedural law of international tribunals traditionally does not include strict rules on admissibility of evidence. The standard of proof,

24 Yann-huei SONG, The South China Sea Arbitration Case Fielded by the Philippines against China:Arguments concerning Low Tide Elevations, Rocks and Islands, 21 China Oceans Law Review (2015), p. 295.

25 Article 22(2) of Rule of Procedure provides that the Arbitral Tribunal may take all appropriate measures in order to establish the facts including, when necessary, the conduct of a visit to the localities to which the case relates. The Parties shall afford the Arbitral Tribunal all reasonable facilities in the event of such a visit.

26 Foreign Ministry Spokesperson Hua Chunying's Remarks on the Philippines' Efforts in Pushing for the Establishment of the Arbitral Tribunal in Relation to the Disputes between China and the Philippines in the South China Sea, available at the website of the Ministry of Foreign Affairs of China, http://www.fmprc.gov.cn/web/wjdt_674879/ fyrbt_674889/t1035477.shtml (last visited on 3 February 2016).

Award, p. 20, para. 60. 
relevance and admissibility of evidence are all decided by the Arbitral Tribunal. ${ }^{28}$ It is admitted that this flexibility could affect evaluation of evidence negatively. Take the relevance of evidence for example. There are four types of evidence: documentary evidence, physical evidence, direct and indirect evidence. It is rare that physical evidence appears in the arbitration, thus indirect evidence is the most common type. In the present case, most materials submitted by the Philippines were selected, disguised or even manipulated by its counsels. Consequently, either some irrelevant evidence were misinterpreted and repeated, or suspicious ones appeared before the Tribunal, thus making the Award questionable.

The Arbitral evidence system itself is of multi-aspects and complex, and its practice is also vague and subtle. China has stated that it will neither accept nor participate in this Arbitration initiated by the Philippines. But without China's cooperation, the Tribunal will find it hard to identify the objective fact and apply the appropriate law to the facts. While being fully aware that its claims essentially deal with territorial sovereignty, China has never accepted any compulsory procedures in respect of those claims. Despite the fact that there has been an agreement existing between the two States to settle their relevant disputes by negotiations, the Philippines has nevertheless initiated, by unilateral action, the present Arbitration. This unilateral initiation runs counter to the consensus between the two countries, the stipulations of UNCLOS and basic legal principles of arbitration. ${ }^{29}$

\section{The Specific Problems of Fact-Finding in Identification and Characterization of the Dispute}

This section makes further analysis of the Award following the reasoning of the Tribunal mentioned above, discussing the second step of the foregoing reasoning to determine whether there is a dispute between the Parties concerning the matter raised by the Philippines (Article 288). In the Tribunal's view, China's Position Paper and communications constituted a plea on jurisdiction. Accordingly, in the Award, there are summaries of the two Parties' position,

28 Rüdiger Wolfrum, Mirka Möldner, International Courts and Tribunals, Evidence, Max Planck Encyclopedia of Public International Law [hereinafter MPEIL], paras. 2, 8.

29 The South China Sea Arbitration Initiated by the Philippines is a Threat to Peace and Stability in the South China Sea, available Mission of the People's Republic of China to the European Union, http://www.chinamission.be/eng/more/SouthChinaSeaIssue160420001/ t1357241.htm (last visited on 25 April, 2016). 
followed by the Tribunal's two principles drawn from other courts' jurisprudence. First, where a Party has declined to contradict a claim expressly or to take a position on a matter submitted for compulsory settlement, the Tribunal is entitled to examine the conduct of the Parties and draw appropriate inferences. Second, the existence of a dispute must be evaluated objectively. ${ }^{30}$ The specific problems in this respect are: the evidence used is irrelevant to the facts to be established (3.1); and the contents of the evidence are ambiguous (3.2). A summary follows (3.3).

\subsection{Irrelevant Evidence}

Relevant evidence is the evidence that has some extent of connection with facts. As regards to Submission No. 1 and No. 2, the Tribunal examined four Notes Verbales as evidence produced by the Philippines in order to identify a dispute existing between the Parties. These are two Chinese Notes Verbales No. CML/17/2009 and No. CML/18/2009 of May 2009 addressed to the SecretaryGeneral of the United Nations, contents of which are the same. The other two are Notes Verbale No. 000228 from the Philippines to the Secretary-General of the United Nations, and No. CML/8/2011 from China to the Secretary-General of the United Nations. ${ }^{31}$

Three Notes Verbales and one Memorandum are used as evidence for Submission No. 3, 4, 5 and $7 .{ }^{32}$ In addition to the Notes Verbales No. CML/8/2011 and No. 000228, another two documents are Notes Vearbales No. 110885 from the Department of Foreign Affairs of the Philippines to the Embassy of China in Manila, a Memorandum from Rodolfo C. Severino to the President of the Philippines is included. The Tribunal did not cite the whole paragraphs of these documentary evidence, and simply agreed that disputes exist. This article argues that the whole contents of these documentary files are relevant to the fact to be proven.

First, the Tribunal neglected the background of the Notes Verbales, which was very complicated. Take Notes Verbales No. CML/17/2009 and No. CML/18/2009 for example. Malaysia and Vietnam issued a joint submission to the Commission on the Limits of the Continental Shelf concerning the outer limits of the continental shelf beyond 200 nautical miles on 6 May 2009; Vietnam also issued a submission to the same Commission on the same issue on the next day. China presented its position to the Secretary-General of the United Nations on 7 May 20og. That is the background of the two Notes

$\begin{array}{ll}30 & \text { Award, p. } 45, \text { p. } 64 \text {, paras. } 132,163 . \\ 31 & \text { Award, pp. } 64-65 \text {, paras. } 164-168 \text {, footnotes } 128-130 . \\ 32 & \text { Award, pp. } 66-67 \text {, paras. } 169-171 \text {, footnotes } 132-135 .\end{array}$ 
Verbales. Two years later, the Philippines presented its protest with reference to the two China's Notes Verbales and emphasized that the Philippines has sovereignty and jurisdiction over some features in the Kalayaan Island Group (KIG). China presented its comments with reference to No. 000228 of the Philippines in Note Verbale No. CML/8/2011 on 11 April 2011 to the Secretary-General of the United Nations, and reiterated the Chinese position. ${ }^{33}$ Accordingly, Note Verbale No. CML/17/2009 is the response to the joint submission by Malaysia and Vietnam, while Note Verbale No. CML/18/2009 is to the Vietnam submission alone. The receiver of these two Notes Verbles is not the Philippines, thus they are not relevant to the fact in this case.

Secondly, even assuming, arguendo, that the two Notes Verbales were concerned with the facts need to be proved, the Tribunal did not examine the two Notes Verbales that relevant to the Parties No. 000228 and No. CML/8/2011) in their entirety. For instance, ${ }^{34}$ the Tribunal neglected the preface and the first paragraph of Note Verbale No. 000228, and only quoted the second and third paragraphs. ${ }^{35}$ The preface and the first paragraph of the Note Verbale No. 000228 stated that KIG constituted an integral part of the Philippines and that it has sovereignty and jurisdiction over some features in the KIG. What was objected strongly by China in Note Verbale No. CML/8/2014 is that the Philippines has started to invade and occupy some islands and reefs on China's Nansha Islands, as well as other related acts which constitute infringement upon China's territorial sovereignty. ${ }^{36}$ Therefore, from the paragraphs that the Tribunal omitted, we learn that the real dispute between the Philippines and

33 Foreign Ministry Spokesperson Ma Chaoxu's Remarks on Vietnam's Submission on Outer Limits of the Continental Shelf in South China Sea, available at the website of the Ministry of Foreign Affairs of China, http://www.fmprc.gov.cn/123/xwfw/fyrth/t561316 .htm (last visited on 3 February 2016); Foreign Ministry Spokesperson Ma Chaoxu's Remarks on China's submission of the preliminary information on the outer limits of the continental shelf beyond 200 nautical miles, available at the website of the Ministry of Foreign Affairs of China, http://www.fmprc.gov.cn/123/xwfw/fyrth/t561647 .htm (last visited on 3 February 2016); Foreign Ministry Spokesperson Hong Lei's Regular Press Conference on April 14, 2011, available at the website of the Ministry of Foreign Affairs of China, http://www.fmprc.gov.cn/web/fyrbt_673021/jzhsl_673025/t815309.shtml (last visited on 3 February 2016).

On 9-10 January 2016, at the seminar on The South China Sea Arbitration Case held by Chinese Society of International Law and The Department of Treaty and Law of Ministry of Foreign Affairs of China, the incomplete citation of Note Verbale No. 000228 was pointed out by Professor Sheng-ti Gau.

35 Award, p. 64, para. 165.

36 See Note Verbale No. CML/8/2011. 
China is territorial sovereignty, which is already excluded by Article 297 of the Convention and China's 2006 declaration filed under Article 298, as beyond the interpretation or application of the Convention.

Let us consider the matter of the Note Verbale No. $110885,{ }^{37}$ which was supposed to respond from the Philippines side to the two Notes Verbales No. (10)PG-047 and No. (10)PG-137 from the Embassy of China in Manila to the Department of Foreign Affairs of the Republic of the Philippines. The contents of the latter two documents are on the Philippines Department of Energy's awarding of Service Contract relating to the so-called "GSEC 101" license that related to the Reed Bank. In these two Notes Verbales, China had expressed its consistent position, that is China has indisputable sovereignty, sovereign rights and jurisdiction over Nansha Islands and its adjacent waters and the illegal, null and void behavior of the Philippine has seriously infringed upon china's sovereignty and sovereign rights. China also warned the Philippines not to violate the ASEAN-China Declaration of Conduct on the South China Sea (DOC). On the other hand, there are four reasons in the Philippines' Note Verbale No. 110885 to maintain that its action was fully consistent with international law. However, the Tribunal only quoted the last three reasons, while omitted the first one that the Philippines claimed its sovereignty and jurisdiction over KIG. There are two major problems if we review completely the background and contents of the Notes Verbales as evidence. One is that the Note Verbale No. 110885 , as evidence for Submission No. 3, 4, 6, and 7, relating to a specific maritime region, Reed bank, is not relevant to the maritime features in the four claims. The other is that the dispute reflected in Notes Verbales is a territorial sovereignty dispute, not the one concerning interpretation or application of the Convention.

\subsection{The Content of Documentary Evidence is not Definitive}

The content of documentary evidence cited by the Tribunal is not only not definitive but also conflicting with the Philippine's claims. In Note Verbale No. 00028, the Philippines claimed its sovereignty for KIG in the first paragraph. It also stated in paragraph 3, "sovereignty and jurisdiction or sovereign rights, as the case may be, necessarily appertain or belong to the appropriate coastal or archipelagic state-the Philippines-to which these bodies of waters as well as seabed and subsoil are appurtenant, either in the nature of Territorial Sea, or 200 M Exclusive Economic Zone, or Continental Shelf." From this paragraph, the maritime rights claimed by the Philippines are not clear. On the one hand, the Philippines advocated itself as a coastal state; on the other hand, it

Award, p. 67, footnote 135 . 
labeled itself as an archipelagic state and claimed that some maritime features can generate territorial sea. These two claims are contradictory. These claims of the Philippines are so vague that it is impossible to constitute the supportive evidence for Submission No. 1 and 2.

By contrast, China's claims to Nanshan islands are clear and consistent. China has always enjoyed sovereignty over the Nansha Islands in its entirety. Many legal documents show this, such as the Map of the Location of the South China Sea Islands of 1948, the Declaration of the Government of the People's Republic of China on the Territorial Sea of 1958 and the Law of the People's Republic of China on the Territorial Sea and the Contiguous Zone of 1992. These documents all provide that the Nansha Islands constitute an integral part of the land territory of China. This is in sharp contrast to the Philippines' position. Prior to the 1970s, the Philippines' national law had set clear limits for the territory of the Philippines, which did not involve any of China's maritime features in the South China Sea. It was the same in the international treaty ratified by Philippines. ${ }^{38}$ The Tribunal should have noticed this vague and conflicting position of the Philippines reflected in the documentary materials.

As for the Philippines' Submissions No. 8 to 14, the Tribunal simply concluded that "the incidents giving rise to these Submissions are well documented in the record of the Parties' diplomatic correspondence and the Tribunal concludes that disputes implicating provisions of the Convention exist", without any reasoning. ${ }^{39}$ If the tribunal had carefully reviewed the record of the Parties' diplomatic correspondence, it would find that this is not the case. For instance, the Tribunal mentioned a transcript of the two Parties' bilateral talks on 9 August 1995 about Meiji/Mischief Reef. Indeed, Meiji/Mischief Reef was mentioned in this transcript. However, what exactly Philippines expressed was its concerns about China's installation on Mischief Reef, not only because of its proximity to Palawan, but also due to the possibility that such Chinese actions may take place elsewhere inside the KIG. Meanwhile, the Chinese position in the transcript was, "The dispute between us is mainly centering around the issue of sovereignty. We say that we have sovereignty over the Nansha islands and you say that you have sovereignty over part of the Nansha in what you call the Kalayaan group of islands. This is our basic difference. Of course, arising from this, there may be other issues such as maritime jurisdiction."

Obviously, the essence of the subject-matter of the arbitration is the territorial sovereignty over several maritime features in the South China Sea, which is beyond the scope of the Convention and does not concern the

\footnotetext{
38 Position Paper, paras. 5, 6 .

39 Award, para. 173 .
} 
interpretation or application of the Convention. In addition, as for the issue whether Submission No. 5 relates to the interpretation and application of the Convention, there is no evidence mentioned in the Award and the Tribunal's conclusion has no factual basis. ${ }^{40}$

\subsection{Summary}

As the fact proved by the evidence must have an objective connection with the fact to be proved in the specific case, the objective connection is of theoretical and practical significance. However, in the present case, some of the contents in the Notes Verbales mentioned above have no actual connection with the fact to be proven. The Arbitrators cannot dream up some objective connection when analyzing the case or stretch the rules to suit the Philippines' needs.

As mentioned above, the Tribunal is entitled to draw appropriate inferences form the Parties' conducts and evaluate them objectively, when deciding the existence of a dispute. Inferences are judicial tools and they relate to the specific context of the evidence. A tribunal or court decides in the exercise of its judgment whether they are reasonable. In the context of international litigation, the provisions on evidence of the ICJ and of the ITLOS do not refer to the use of inferences as evidence. Nevertheless, international adjudicative bodies make use of reasoning based on inferences or presumption. It is common to distinguish between inferences (presumptions of fact) and presumptions prescribed by law (legal presumptions). Inferences are established tools of reasoning. Based upon general experience, judges or arbitrators may draw conclusions from certain established facts. ${ }^{41}$ The ICJ stated in Corfu Channel Case that if the proof is drawn from inferences of fact, those facts must not leave room for reasonable doubt. Apart from that, whether an inference can be made is for the adjudicative body in question to decide. ${ }^{42}$ The precedents of international courts are frequently used in the process of inference. In this case, the Tribunal concluded that inference can be drawn from the ICJ's preliminary objections judgment in South West Africa (Ethiopia v. South Africa; Liberia v. South Africa) case, which established that "the existence of a dispute in international law generally requires that there be 'positive opposition' between the parties." ${ }^{33}$ Nevertheless, in the Judgment of Georgia v. Russian Federation, "the Court's determination must turn on an examination of the facts. The

\footnotetext{
$40 \quad$ Award, para. 172.

41 MPEIL, para. 68.

42 MPEIL, para. 69.

43 Award, p. 62, para. 159.
} 
matter is one of substance, not of form", ${ }^{44}$ the ICJ again emphasized, "the Parties gave their main attention to the contents of the documents and statements and the Court will do likewise." ${ }^{45}$ No matter what the rule of inference adopted by the Tribunal, it must sufficiently prove, and there is no contrary evidence to rebut this inference. From the analysis above, the precedents in these two ICJ case were not satisfied, either of the fact "positive opposition" or "the fact that a dispute concerning interpretation or application". Also, there is not any reasoning process of the arbitrators on the Submissions No. 8 to 14. The principle of discretionary assessment of evidence however does not absolve international courts and tribunals from indicating how they have reached their conclusions. ${ }^{46}$ In a word, how to reason should not just lie in the heart of the arbitrator, but should be open to the public. This is the essential significance of proper administration of justice and fair trial.

Indeed, as the Award shows, "a dispute may have different elements," which does not "preclude some elements from falling within jurisdiction". ${ }^{47}$ However, the relevance of evidence is a crucial point that cannot be ignored. Those Notes Verbles and documents are more complex than it seems at first glance, thus should be examined carefully and intensively. The best practice would be to review every document, statement and resolution after the Convention coming into force, then draw carefully a general conclusion from these documents as a whole. The ICJ adopted this approach. ${ }^{48}$ Therefore, in the process of identification and characterization of the dispute, the Tribunal is not up to its standard set in the Award, namely, appropriate inference and evaluates the evidence objectively.

The Specific Problems of Fact-finding in Deciding the Precondition to the Tribunal's Jurisdiction

After ascertaining the dispute (as stated above, it was dubious in proof), the Tribunal turned to analyze whether there are any circumstances that would preclude access to the compulsory dispute settlement procedures in Section 2

\footnotetext{
44 Application of the International Convention on the Elimination of All Forms of Racial Discrimination (Georgia v. Russian Federation), [2011] ICJ Reports, p. 84, para. 30.

45 Ibid., p. 87, para. 37 .

46 MPEIL, para. 6.

47 Award, p. 49, para. 142.

48 Application of the International Convention on the Elimination of All Forms of Racial Discrimination (Georgia v. Russian Federation), [2011] ICJ Reports, p. 88, para. 39.
} 
of Part XV of the Convention and thus bar its jurisdiction over the Philippines' claims. Article 281, 282 and 283 are discussed respectively.

Deviating from the precedent established by the other international courts and tribunals, the Tribunal took a different approach to the interpretation of Article 281. It reasoned that "if the States Parties which are parties to a dispute concerning the interpretation or application of this Convention have agreed to seek settlement of the dispute by a peaceful means of their own choice". The reasoning of the Tribunal was like this: to decide whether such an agreement exists; if the answer is no, Article 281 poses no obstacle to jurisdiction. If there is such an agreement, the compulsory procedures of Section 2 of Part XV will only be available if (i) no settlement has been reached by recourse to the agreed means, (ii) the Parties' agreement does not exclude any further procedure, ${ }^{49}$ and (iii) the agreed time limits have expired. ${ }^{50}$

This interpretation of Article 281 by the Tribunal virtually sets a high standard for precluding its jurisdiction, but this strict method did not continue to be used in interpreting Article 283. Conversely, it adopted a loose and flexible way in interpreting whether the Parties have engaged in "exchange of views" as required by Article $283 .{ }^{51}$ The Tribunal noted that the position on the application of Article 283 of the Parties "reflects the fact that diplomatic communications and exchanges do not divide neatly between procedural and substantive matters". ${ }^{52}$ This section continues to discuss how the preconditions in Article 281 and 283 have been satisfied from the evidence and fact-finding perspective. Some specific problems still existed; some evidence are not allowed to come into the proceedings (4.1). There is room for improvement in evaluating the evidence (4.2), followed by a summary (4.3).

\subsection{Some of the Evidence are Inadmissible}

The Philippines chose some bilateral consultation records as evidence, which encompassed two summaries of proceedings on 20-21 March $1995,{ }^{53}$ a Note Verbale No. 12-1137 of 26 April 2012 from the Department of Foreign Affairs of the Philippines to the Embassy of China in Manila, a Note Verbale No. (12) PG-206 of 29 April 2012 from the Embassy of China in Manila to the Department of Foreign Affairs of the Philippines. ${ }^{54}$ Taking the exchanges and

\footnotetext{
49 Award, p. 87, para. 224, "This requires an 'opting out' of Part XV procedures...."

$50 \quad$ Award, p. 76 , para. 195.

$51 \quad$ Award, p. 122, para. 349.

$52 \quad$ Award, p. 115, para. 332.

53 Award, pp. 115-116, paras. 334, 335, footnotes 304, 305.

54 Award, pp. 118-119, paras. 337-341.
} 
records together, the Tribunal was convinced that the Parties have unequivocally exchanged views regarding the possible means of settling the disputes between them, ${ }^{55}$ and thus the requirements in Article 283 have been satisfied. Thereafter, the Tribunal "has well established that the Philippines was not obliged to continue with an exchange of views when it concludes that the possibilities of reaching agreement have been exhausted." 56

However, in the author's view, these documents as evidences are inadmissible. As stated in footnote 303 in the Award that:

The majority of the records of the Parties' consultations available to it are the Philippines' internal records and are therefore less authoritative as to what was said than a record that was prepared jointly. The Tribunal nevertheless considers that the Philippines' diplomatic records do have evidentiary value insofar as they were contemporaneous to the events in question and were prepared in the course of the Philippines' normal diplomatic practice. ${ }^{57}$

However, in practice, it can be problematic for evidence obtained through settlement negotiations. As a rule, settlement negotiations between the parties to a dispute are held on the understanding between them that, in case the negotiations failed to produce a settlement, positions taken in the course of such negotiations and information and documents produced solely for that purpose will not be used against the parties in any pending or future litigation. Moreover, where parties reach a provisional agreement, they generally provide that, unless and until there is final agreement, the parties will not refer to the contents of their agreement in any proceedings. ${ }^{58}$ This principle has been adopted in some agreements between States as a rule of procedure to be applied in international litigation. For instance, Article v(1) of the Special Agreement of March 29, 1979 between the us and Canada in the Gulf of Maine Case provided:

Neither party shall introduce into evidence or argument, or publicly disclose in any manner, the nature or content of proposals directed to

\footnotetext{
55 Award, p. 119, para. 342.

56 Award, p. 120, para. 343 .

57 Award, p. 115, footnote 303 .

$5^{8}$ Chittharanjan F. Amerasinghe, Evidence in International Litigation, pp. 174-177.
} 
a maritime boundaries settlement or responses thereto, in the course of negotiations or discussions between the Parties undertaken since 1969. ${ }^{59}$

More importantly, in the present case, the three bilateral consultations records ${ }^{60}$ are internal and unilateral records, whose weight of proof can be questioned without two Parties' signatures. They cannot be accepted by the Tribunal. Ironically, the Tribunal recognized the said records with defects as evidence, while cited another Memorandum that had the signatures of the Parties on it as proof that the DOC is a political undertaking. That is a manifestation of the Tribunal capable of selective evidence.

In order to prove DOC as a non-binding political instrument, the Philippines referred to a 2010 article, titled ASEAN and the South China Sea, authored by the former Secretary-General of ASEAN, Rodolfo Severino, stating that a range of disagreements over many aspects of South China Sea reduced the originally envisioned legally binding code of conduct to a mere "political declaration". ${ }^{61}$ Nevertheless, in the ICJ's judgement in Nicaragua v. United States of America, it stated that:

At all events, the Court has before it documentary material of various kinds from various sources. A large number of documents have been supplied in the form of reports in press articles, and some also in the form of extracts from books. Whether these were produced by the applicant state, or by the absent Party before it ceased to appear in the proceedings, the Court has been careful to treat them with great caution; even if they seem to meet high standards of objectivity, the Court regards them not as evidence capable of proving facts, but as material which can nevertheless contribute. ${ }^{62}$

59 Delimitation of the Maritime Boundary in the Gulf of Maine Area (Canada/United States of America), [1984] ICJ Reports, p. 254.

6o These three bilateral consultations records are respectively, Philippine-China Bilateral Consultations: Summary of Proceedings (20-21 March 1995); and Republic of the Philippines, Department of Foreign Affairs, Record of Courtesy Call on Chinese Vice Premier and Foreign Minister Qian Qichen (21 March 1995); Summary of Proceedings: PhilippineChina Bilateral Consultations. Also see Award. p. 114, footnote 295.

61 Award, pp. 84-85, para. 217, footnote 203, Rodolfo Severino, ASEAN and the South China Sea, 6(2) Security Challenges 45 (2010).

62 Military and Paramilitary Activities in and against Nicaragua (Nicaragua v. United States of America), [1984] ICJ Reports, p. 419 para. 62. 
Though the author of the article was the former Secretary-General of ASEAN, this article is still an academic paper, which only represents personal viewpoints. It did not have any evidentiary effect on the legal status of the Doc. Rodolfo Severino was both the former ASEAN Secretary-General and the former Vice Foreign Minister of the Foreign Affair Department. It should be pointed out that there are a couple of documents relating to Rodolfo Severino in the Award. On top of this, Memorandum from Rodolfo C. Severino is being offered to prove "the Parties appear to have only rarely exchanged views concerning the status of specific individual features" ${ }^{63}$ which is the only one piece of document to prove the fact.

\subsection{Incomplete Review of the Evidence}

When interpreting Article 283, the Tribunal did not adopt the same strict approach. The record of discussion on 17th Philippines-China Ministry Consultations was mentioned in the Award. This record was produced during the fourth Senior Officials' Meeting on 14 January 2012. ${ }^{64}$ The 17th PhilippinesChina Ministry Consultations was hosted by Liu Zhenmin and Erlinda Basilio, the two sides talked on the arrangements of friendly exchanges and cooperation in all fields from 2012 to 2013. ${ }^{65}$ Except the flaw of this internal record as evidence, another problem is about the Tribunal's incomplete citing of the record. The Award cited paragraphs 134 to 141,148 and 149. The omitted paragraphs among these are the trade interest of the Parties, regional tension ${ }^{66}$ and the consultation on the Doc. None of these was exchanged on the dispute settlement procedure of the interpretation or application of the Convention. Against this background, we can see the fact that the two Parties did exchange views over many aspects, including the measures and cooperation on preventing conflicts, reducing frictions, maintaining stability and promoting trade.

63 Award, para. 169, footnote 132, Memorandum from Rodolfo C. Severino, Undersecretary, Department of Foreign Affairs of the Republic of the Philippines, to the President of the Republic of the Philippines (27 May 1997).

64 Foreign Ministry Spokesperson Liu Weimin's Regular Press Conference on January 12, 2012, available at the website of Consulate-General of China in Osaka, http://osaka.chinaconsulate.org/chn/fyrth/t895096.htm (last visited on 3 February 2016).

65 The 17th Philippines-China Ministry Consultations was Hosted, available at the website of the Embassy of China in the Philippines, http://www.fmprc.gov.cn/ce/ceph/chn/zfgx/ zzgx/t896229.htm (last visited on 3 February 2016).

66 Philippines maintained Chinese Warships Ran into its Territorial Waters and Expressed Great Concern to China, available at the website of News Sohu, http://news.sohu.com/20120109/ n331557975.shtml (last visited on 3 February 2016). 
They are far from constituting negotiations as the evidence presented and interpreted by the Philippines.

In reasoning Article 281, a statement was cited from the Spokesperson's Comment on China-Asean Consulation, "Code of Conduct will be a political document to promote good neighborliness and regional stability instead of a legal document to solve specific disputes." ${ }^{\prime 67}$ Actually, there are three parts in this Comment: disapproval of the draft of ASEAN, practical ways of the Chinese draft and request for consideration of the Chinese draft. The meaning of the very words which Chinese spokesman utilized here was that "The Code of Conduct is a principle political consensus that built on existing willingness of the ASEAN countries".

Moreover, remarks by a Chinese senior official during the 16th ASEAN-China Summit in $2013^{68}$ was also presented in the reasoning for proving the Doc's binding force, whose original content was missed. Upon inspection, the original text is "DOC, as an important political agreement reached among China and ASEAN countries, constitutes the cornerstone for peace and stability in the South China Sea." ${ }^{\prime \prime}$

First, whether or not a "political agreement" or "political document" is legally binding is still an open question of international law, which always depends on specific context. Second, it is true that the intention of the Parties may be inferred from the circumstances of its conclusion. However, this is not always the case, and it is sometimes difficult to draw conclusion solely from the terms of the instrument itself and the circumstance when the DOC was signed. The subsequent acts of the Parties are also relevant, which sometimes can make the nature of the instrument change. The Tribunal should have noted that, since the Doc was signed, the Philippines and China have ratified a large number of bilateral joint statements or communiques. And the two Countries expressed on many occasions that it was essential for the two countries to put efforts together to work closer to the full and effective implementation of the Doc. ${ }^{70}$ For example, a Joint Press Statement between China and the Philippines

67 Award, p. 84, para. 217.

68 Award, p. 85, para. 218.

69 Remarks by H. E. Li Keqiang, Premier of the State Council of the People's Republic of China At the 16th. ASEAN-China Summit, available at the website of the China Government website, http://www.gov.cn/ldhd/2013-10/10/content_2503038.htm (last visited on 3 February 2016).

70 For inferences see Song Yann-huei, The South China Sea Arbitration Case Filed by the Philippines against China: A Discussion on Preliminary Objections to the Tribunal's Jurisdiction; also see Bing Bing Jia, The Issue of Admissibility in Inter-State Arbitration, in 
was issued on 3 September 2004 and a Joint Statement between China and the Republic of the Philippines on 3 September 2011. ${ }^{71}$ Thus, as to the nature and status of the Doc, the Tribunal should not make decision on a single statement or remark as evidence. Even for this statement and remark, it had not evaluated objectively and completely, even intentionally distorted the original text. Thirdly, whether the DOC was intended to create legal rights or obligations should be inferred from every practice of all of the relevant Parties in ASEAN rather than from only one Party. There are much more evidence at China and other ASEAN countries disposal and they can illustrate the real nature and status of the Doc. This is also reflecting the general problems of producing evidence unilaterally that stated in Section 2 of the article. ${ }^{72}$ Moreover, in the foregoing documents, the two Countries referred to have clearly demonstrated the respect for the international law and the Doc in many occasions. ${ }^{73}$

\subsection{Summary}

In general, the international courts or tribunals have the power to receive every kind and form of evidence, and have attached to them the probative value they deserve under the circumstances of a given case. Even the international courts or tribunals have the power to admit evidence of all kinds, the practice in this regard is still governed by some general principles of law. For example, evidence obtained through settlement negotiations, the irrelevant evidence or the evidence lacking reliability and damages the integrity of the proceedings, especially the documents lacking authenticity or signature, are all inadmissible evidence. Moreover, the admissibility of evidence is a crucial issue that the courts or tribunals need to tackle first. For instance, similar issues were also dealt with recently in Croatia v. Serbia Case. The ICJ emphasized that:

The Court recalls that neither its Statute nor its Rules lay down any specific requirements concerning the admissibility of statements which are presented by the parties. The Court has to ensure that documents faithfully record the evidence actually given by those not appear individuals. Moreover, the Court recalls that even affidavits will be treated "with caution". In determining the evidential weight of any statement by an

Stefan Talmon, Bing Bing Jia (eds.), The South China Sea Arbitration: A Chinese Perspective, pp. 107-137.

$71 \quad$ Position Paper, paras. 36, 37.

72 MPEIL, para. 14.

73 See the Note Verbale No. 110885, the 17th Philippines-China Ministry Consultation and the Notes Verbales No. (10)PG-047. 
individual, the Court necessarily takes into account its form and the circumstances in which it was made. ${ }^{74}$

The ICJ thus concluded that some statement without personal signature afforded by Croatia is inadmissible. On the other hand, as regards the threshold required by Article 283 (obligation to exchange), this is a matter of fact that cannot prove easily. ${ }^{75}$ The obligation is in practice an obligation of the Parties to seek to settle their dispute by recourse to negotiations, it is an obligation both in form and in substance, and every Party must take it seriously. This is fully supported by the cases in the International Tribunal of Law of Sea. ${ }^{76}$ Stefan Talmon, a professor of public international law at the University of Bonn, Germany, said in his publication that:

The standard for satisfying UNCLOS, Article $283(1)$ is not a purely subjective one. If the applicant could simply claim that the possibilities of reaching a settlement of the dispute by way of exchanging views have been exhausted, the provision would have no substance. Instead, it is for the applicant to prove, and for the Tribunal to determine, that an exchange of views was held or, at least, that it invited the other party to an exchange of views which was open to the possibility of a settlement of the dispute by negotiations or other peaceful means. ${ }^{77}$

He also pointed out that:

The parties need not necessarily expressly refer to the provisions of the Convention at issue in the dispute in their exchanges of views. However, to meet the pre-condition of negotiations, the subject matter of the negotiations must be identical with the subject matter of the dispute.

74 Application of the Convention on the Prevention and Punishment of the Crime of Genocide (Croatia v. Serbia), Judgment, paras. 196-199.

75 Stefan Talmon, The South China Sea Arbitration: Is There a Case to Answer?, in Stefan Talmon and Bing Bing Jia (eds.), The South China Sea Arbitration: A Chinese Perspective, p. 62 .

${ }_{76}$ See $M / V$ 'Louisa' (Saint Vincent and the Grenadines $v$ Kingdom of Spain), Provisional Measures, Order of 23 December 2010; Land Reclamation in and around the Straits of Johor (Malaysia v Singapore), Provisional Measures, Order of 8 October 2003.

77 See Land Reclamation in and around the Straits of Johor (Malaysiav Singapore), Provisional Measures, Order of 8 October 2003. 
That is to say, the interpretive approach adopted by the Tribunal was totally different from the existing practices. The Tribunal took it for granted that the Parties only need to exchange their views on dispute settlement procedures rather than the virtual settlement of dispute. The documents produced by the Philippines only reflected that the two Countries exchanged views on some similar issues, which were not the same as those claimed in the present case. The obligation of the Tribunal in this regard must be discharged in good faith, and it is the duty of the Tribunal to examine whether this is being done as well. ${ }^{78}$

Since the 199os, an inescapable fact is that China and the ASEAN Countries had many bilateral talks and consultations, among which several meetings were held between the Philippine and China. If, as the Tribunal reasoned, the threshold of the exchange of views in Article 283 must be satisfied automatically. This article suggests the Tribunal to shift the focus of the nature of the current diplomatic relationships. Diplomatic relations are the management of relationship and dealings between two countries, on the basis of equality, mutual benefit and mutual respect for territorial integrity and sovereignty. And the essence of establishing diplomatic relations is to exchange views on issues of common concern in order to promote further development of bilateral friendly relations. If the reason of the Tribunal is tenable, the exchange of views is an inevitable result of diplomatic relations. General exchanges of views, without having the purpose of settling a given dispute, do not constitute negotiations. It is of particular importance for the Tribunal to prove the fact.

Admissible evidence is a prerequisite for evaluating and interpreting the fact. When the production of evidence is complete, the tribunal must consider the evidence objectively and completely. This article finds that the Tribunal seems to "split" each document and statement in order to support the Philippines' claims. It is improper for the Tribunal to comprehend, evaluate and interpret the evidence in this manner.

\section{5 The Possible Problems of Fact-finding on the Merits Decision}

According to the open information from the PCA's website, the Tribunal commenced the hearing on the merits and remaining issues of jurisdiction and admissibility on 27 to 30 November 2015. Prior to the hearing, the Philippines submitted further written responses to the questions posed by the Arbitral

78 Stefan Talmon, The South China Sea Arbitration: Is There a Case to Answer? p. 63. 
Tribunal. Additionally, the Tribunal heard expert testimony from Professor Clive Schofield and Professor Kent Carpenter. ${ }^{79}$

In the merits stage, the Philippines produced lots of evidence to support its claim, containing figures, maps, nautical charts, documentary exhibits, expert reports and witness affidavits. From reading the transcripts, a large collection of scientific and technical evidence about the islands, rocks and maritime features were shown by the Philippines' counsels. How the Tribunal deals with these materials is still unclear. This article points out that the traditional methods of evaluating evidence are deficient in assessing the relevance of such complex, technical and scientific facts (5.1). The question remains in evaluating academic papers as evidence (5.2). In the summary, combining the international arbitration's characteristic and the past practice of the ICJ, in the merits stage, the Tribunal will have no way of judging the facts legitimately only based on the evidences unilaterally produced by the Philippines(5.3).

\subsection{It is not an Easy Task to Evaluate the Scientific and Technical Evidence}

Many scientific and technical evidence were presented in the merits stage; the examples are as follows.

Example 1: To prove the five maritime features including Mischief Reef, Second Thomas Shoal, Subi Reef, Gaven Reef and McKennan Reef (including Hughes Reef) are low-tide elevations, the counsels of the Philippines collected and showed lots of hydrologic, geographical and historical data, consisting mainly of the high-resolution satellite images from EOMAP, a German company that specializes in generating bathymetric models. ${ }^{80}$ EOMAP is a company that the Philippines have engaged since the proceeding began, and relevant charts and satellite data from different countries were cited. ${ }^{81}$

Here are questions from the Arbitrators during the exhibition of the evidence, "whether the available evidence is consistent", "whether the available evidence suffices to establish the status of features as above or below water at high tide in the absence of direct observation", "whether existing models of tidal patterns... are sufficiently complete and reliable", and "whether

\footnotetext{
79 Ninth Press Release 30112015.

80 "Philippines has since engaged the services of EOMAP to provide a detailed analysis of satellite imagery relation to the five features identified by the Philippines as low-tide elevations", "Final Transcript Day 2-Merits Hearing [hereinafter Day 2]", available at the website of PCA, http://www.pcacases.com/web/sendAttach/1548 (last visited on 3 February 2016), p. 26, lines, 15-19.

81 Day 2, pp. 38-40.
} 
measurements and models of tidal patterns... by both the Philippines and China... differ significantly". ${ }^{2}$

Example 2: For proof Submission No. 12(b) of marine environmental effects, the Counsel cited two reports from Professor Kent E. Carpenter, ${ }^{83}$ they are Eastern South China Sea Environmental Disturbances and Irresponsible Fishing Practices and their Effects on Coral Reefs and Fisheries and Environmental Consequences of Land Reclamation Activities on Various Reefs in the South China $\mathrm{Sea}$. The first report describes the harm caused by that sedimentation on fragile reefs and their ecosystem. Professor Carpenter and his co-author L. M. Chou list the harmful environmental effects in greater detail in their second report.

After these two reports were raised, Counsel Allan Boyle was struck dumb by the sharp questions from the Tribunal, "What hard facts do you have that this has been taking place?... so that we find a factual basis for invoking Articles 192 and 194, et cetera", and "But please focus on the facts, so that the facts are clearly in front of us on the table." 84

In the ICJ's precedents, scientific evidence was mainly found in the maritime and environmental cases. In the current examples, though the claims are different, they all involved many technical issues, which are a hard nut to crack for the Tribunal. It is rare practice for the international courts or tribunals to evaluate and interpret this type of evidence. In the past few years, the ICJ had similar problems in a few cases, and was very cautious to deal with them. These similar cases are Pulp Mills on the River Uruguay (Argentina v. Uruguay), Territorial and Maritime Dispute (Nicaragua v. Colombia), Whaling in the Antarctic (Australia v. Japan: New Zealand intervening) and Certain Activities carried out by Nicaragua in the Border Area \& Construction of a Road in Costa Rica along the San Juan River Case.

In the Nicaragua v. Colombia case, the Two Parties had different views on the legal status of maritime features in Quitasueño. Colombia, relying on the expert report produced by Dr. Robert Smith, which argues Grenoble Tide Model was used to determine whether some of the features at Quitasueño are above water at high tide. By contrast, Nicaragua proposed that the "Admiralty

$82 \quad$ See Day 2, pp. 34-39.

83 See Kent E. Carpenter, Ph.D., Eastern South China Sea Environmental Disturbances and Irresponsible Fishing Practices and their Effects on Coral Reefs and Fisheries (22 Mar. 2014); K. E. Carpenter \& L. M. Chou, Environmental Consequences of Land Reclamation Activities on Various Reefs in the South China Sea (14 November 2015); also see "Final Transcript Day 3-Merits Hearing [hereinafter Day 3]", available at the website of PCA, http://www .pcacases.com/web/sendAttach/1549 (last visited on 3 February 2016), p. 14, footnote 4.

84 See Day 3, Merits Hearing, p. 46, lines, 10-18; p. 47, lines, 8-10. 
Total Tide' model" was appropriate. The Court held that it needed be mindful of the volumes of evidence from the Parties and it considered that what was relevant to the issue before it was the contemporary evidence, namely the Smith Report. Nevertheless, the Court still considered that the conclusions of that Report have to be treated with a degree of caution. And no matter which tidal model is used, it is evident that the feature referred to as QS 32 is above water at high tide. Accordingly, the Court concluded that Qs 32 is capable of appropriation. With regard to the other maritime features at Quitasueño, the Court considered that the evidence advanced by Colombia could not be regarded as sufficient to establish its claims, as defined in international law. ${ }^{85}$

In the Whaling in the Antarctic Case, the ICJ needed to decide how to interpret Article 8 of the International Convention for the Regulation of Whaling and whether Japanese Whale Research Program under Special Permit in the Antarctic involved scientific research. The ICJ considered many technical factors, including the scale of the use of lethal methods, the programme's design and implementation, determination of species-specific sample sizes, openended time frame, scientific output of JARPA II to date and co-operation with other research institutions. The ICJ devoted a lot of space to repeatedly stressing these factors and thus adopted some statements and documents agreed by both Parties as the basis for applying international treaty. ${ }^{86}$

It is similar in the present case. The subject matter of this dispute is something mixed with law and science, such as maritime environment, ecological system, and reference tidal datum. The five Arbitrators faced some scientific questions that are beyond their own knowledge background, so they need the professional assistance of scientific experts. As Judges Al Khasawneh and Simma said in the Argentina v Uruguay Case:

The adjudication of disputes in which the assessment of scientific questions by experts is indispensable, as is the case here, requires an interweaving of legal process with knowledge and expertise that can only be drawn from experts properly trained to evaluate the increasingly complex nature of the facts put before the Court. The Court on its own is not

85 Territorial and Maritime Dispute (Nicaragua v. Colombia), Judgment, [2012] ICJ. Reports, pp. 641-648, paras. 25-38.

86 See Whaling in the Antarctic (Australia v. Japan: New Zealand intervening), Judgment, [2014] ICJ Reports.. 
in a position adequately to assess and weigh complex scientific evidence of the type presented by the Parties. ${ }^{87}$

Therefore, how to review and evaluate these scientific evidences is not an easy task, and the arbitrators should be aware that it would be an obstacle for them.

As far as the present Arbitration is concerned, in deciding the legal status of certain insular features without direct observation, there are problems on the two reports of Professor Carpenter. We cannot ignore one point that the two reports are all made after the proceeding initiated by the Philippines. The relevance and reliability of reports therefore is questionable.

The other expert witness, Professor Clive Schofield, raised serious questions as well. Firstly, in his statement in Day 3 hearing, he was called by the Tribunal as an independent expert witness to provide testimony to summarize the findings on the geographical characteristics and status of certain insular features in the South China Sea. However, in his statements and answers, he tried to elaborate and analyse the Convention, ${ }^{88}$ not limited to providing scientific observations as an independent expert witness. An expert witness is required to be independent and address his or her expert report to the court. His task is just to interpret technical information to the Tribunal rather than analyse the law. The expert's job is to assist the Tribunal by clearly presenting his opinion for the Tribunal and therefore to provide a sound basis on which the Tribunal can make its decision after it evaluates all the facts and evidence in the case. It must be understood that interpreting the Convention is not the expert's job. That is counsel's and arbitrator's role.

Secondly, it should be particularly emphasized that Professor Clive Schofiled is not independent. He had a totally different, even contrary viewpoint on the legal status of Taiping Island/Itu Aba in advance of the actual commencement of the present Arbitration. In his statements and answers to the Tribunal, he reached a conclusion that in relation to Taiping Island/Itu Aba, it is most appropriately treated as an Article 121(3) "rock" because Taiping Island Itu Aba lacks the key requirement for full island status. ${ }^{89}$

$87 \quad$ Pulp Mills on the River Uruguay (Argentina v Uruguay), Judgment of 20 April 2010, Joint Dissenting Opinion of Judges Al Khasawneh and Simma, [2010] ICJ Reports, pp. 108, 110, paras. 3, 4 .

88 Day 3, pp. 5-8; "Final Transcript Day 4-Merits Hearing [hereinafter Day 4]", available at the website of PCA, http://www.pcacases.com/web/sendAttach/1550 (last visited on 3 February 2016), pp. $43^{-} 5^{2}$.

$89 \quad$ Day 4 , pp. $47-48$. 
However, Professor Clive Schofield previously wrote that Taiping Island/Itu Aba was inhabited from $1956^{90}$ and "water supply might be one of the most important factors in clarifying the situation [legal status of an island or a rock]. This is because the existence of fresh water is an important indication that human habitation could be sustained." ${ }^{91}$ At that time, he was of the opinion that Taiping Island/Itu Aba "may conceivably" be considered a full-fledged island. ${ }^{92}$ But Professor Clive Schofield's view changed suddenly during the hearing, who now has a firm belief that Taiping Island/Itu Aba is a rock. The Tribunal also found his incoherency of views, asking him whether his position on Taiping Island/Itu Aba has evolved and changed over time. ${ }^{93}$ Can these expert statements become the authoritative and valuable evidence for the Tribunal to find facts? This article strongly suggests the Tribunal should reconsider the objectivity and neutrality of the statement given by Professor Clive Schofield.

A significant issue in many complex cases — such as this present case-is the admission and use of expert statements. A witness qualified as an expert by knowledge, experiences or education, may testify thereto in the form of an opinion or otherwise if (1) the testimony is based upon sufficient facts or data, (2) the testimony is the product of reliable principles and methods, and (3) the witness has applied the principles and methods reliably to the facts of the case, which could be adopted by the Tribunal. ${ }^{94}$ These factors are also emphasized in the foregoing ICJ's cases. On the other hand, scientists and experts draw their conclusions depending on the data they collected, whose character maybe open and unstable. It is important for the arbitrators to understand that different methods utilized to observe the same thing may result in a totally different conclusion.

It should be particularly emphasized that, in the Day 3 hearing, the Philippines' Counsels referred China's violation of environmental impact assessment obligation of international law based on the Argentina v Uruguay Case and the 2001 Articles on Prevention of Transboundary Harm of the

90 Dzurek, Daniel J. and Clive H. Schofield, The Spratly Islands dispute: who's on first (University of Durham, International Boundaries Research Unit, 1996).

91 Yann-huei Song, Philippines' arguments over Taiping status may affect others' claims, available at the website of The China Post, http://www.chinapost.com.tw/commentary/letters-to-the-editor/2016/01/21/456637/Philippines-arguments.htm (last visited on 25 April 2016).

92 See Robert C. Beckman \& Clive H. Schofield, "Defining EEZ Claims from Islands: A Potential South China Sea Change," 29 The International Journal of Marine and Coastal Law (2014), p. 210.

93 Day 4, p. $5^{0 .}$

94 See Manual for Complex Litigation, 4th, §23.22, available at the website of Federal Judicial Center http://www.fjc.gov/public/home.nsf/pages/470(last visited on February 3, 2016). 
International Law Commission. The Counsel said there was simply no evidence that China had carried out such an EIA. In the Philippines' view, there was plainly a breach of Article 206 of the Convention. ${ }^{95}$ However, the fact that no evidence does not indicate no fact happened. The principle actori incumbit probatio (the party which alleges a fact bears the burden of proof) still governs the production of evidence. Unilateral appearance in the Arbitration does not change the principle of the burden of proof.

\subsection{Can Academic Papers be Used as Evidences?}

Many academic papers were also presented in the merit hearing. ${ }^{96}$ The following are the examples.

Example 1: in the Day 2 hearing, Cousel Paul S. Reichler provided such a piece of evidence, a research paper named The Flora of Taipingtao (Aba Itu Island) from the Taiwanese author which was published in $1994 .{ }^{97}$ This research paper was also cited in answering the Tribunal's question 15 in the Day 4 hearing, namely, "Whether Itu Aba is a rock under 3 Article $121(3)$ ".98

Example 2: Chiang Huang-chih is a Taiwanese researcher. His paper Itu Aba claim a distracting waste published on Tapei Times on 27 November 2015 was used by the Counsel, in answering the Tribunal's question about the legal status of Taiping Island/Itu Aba. ${ }^{99}$

From these two above examples, the Counsel from the Philippines collected volumes of evidence to prove the status of Taiping Island/Itu Aba. It is reasonable for Counsels to serve the interest of client, but this does not mean that he can wrench the meaning of the original author. However, Chiang Huang-chih clarified his original meaning, pointing out that it is a translation error of the newspaper. ${ }^{100}$ It is not legitimate and lawful for the Philippine' Counsels to

95 "There is simply no evidence that China has carried out such an EIA. In our view, there is plainly 4 a breach of Article 206.", See Day 3, pp. 36-39; Day 4, pp. 43-52.

96 See for example Final Transcript Day 1-Merits Hearing, available at the website of PCA, http://www.pcacases.com/web/sendAttach/1547 (last visited on 3 February 2016), pp. 28, 31, 32, 33, 45, 82, 83, 84, 86, 91, 92; Day 2, pp. 6, 8, 49, 53, 59, 6o, 62 .

Day 2, p. 111. footnote. 38 , "T-C Huang et al., 'The Flora of Taipingtao (Aba Itu Island), Taiwania, Vol. 39, No. 1-2 (1994), p. 1. MP, Vol. vir".

98 Final Transcript Day 4 [hereinafter Day 4], Merits Hearing, pp. 14-23.

99 Day 4, p. 35, lines, 5-20, footnote $5^{2}$, "Chiang Huang-chih, "Itu Aba claim a distracting waste", Taipei Times (27 Nov. 2015), available at the website of http://www.taipei times.com/News/editorials/archives/2015/04/02/2003614945, (last visited on 3 February 2016).

100 Chiang Huang-chih's statement is available at the website of United Daily News Online, http://udn.com/news/story/1/1435650 (last visited on 3 February 2016). 
willfully intercept, and conceal the real meaning of the author of the academic papers.

In example 1, the report of Professor T-C Huang was completed 20 years ago; it did not follow the method adopted by the ICJ in the Nicaragua $v$. Colombia Case which provides that what was relevant to the issue was the contemporary evidence. No matter how the natural condition was at the time of the report, it will change over time, even dramatically. The natural and economic conditions are just the fact that the tribunal is sorely needed. The Arbitrators actually was aware of this problem when they present the questions. ${ }^{101}$ Therefore, the above evidence should be treated with reserve. Moreover, this report was cited many times by the legal teams of the Philippines, used as the most authoritative evidence to support their argument on Taiping Island/Itu Aba's legal status. As this article mentioned above, the academic papers are purely views expressed by authors or scholars and do not in any way represent the views of any government.

As analyzed above, due to the authorship and the characteristics of academic research, this article argues, academic documentary evidence, such as research papers and reports, does not have the probative value, but just representing certain idea of the scholars in a given period.

\subsection{Summary}

To sum up, this present exceptionally fact-intensive case is like the similar cases in the ICJ, especially for the legal status of maritime features and environmental issues. It raised serious questions as to the role that scientific or technical evidence plays in arbitration proceedings. As far as the Submissions No. 11 and 12 relating to environmental issues that have the feature of indirectness, latency and causality, which cannot be evaluated legitimately and scientifically in a short period of time. As the ICJ observed in its recent Judgment in the Certain Activities carried out by Nicaragua in the Border Area \& Construction of a Road in Costa Rica along the San Juan River Case, the ICJ emphasized that:

It will keeping with the practice in Pulp Mills on the River Uruguay, namely it is the duty of the Court, after having given careful consideration to all the evidence in the record, to assess its probative value, to determine

101 Day 4, p. 50, lines, 11-12, "Turning to question 4, which concerns whether my position on Itu Aba has evolved and changed over time..." 
which facts must be considered relevant, and to draw conclusions from them as appropriate. ${ }^{102}$

In that case, Costa Rica and Nicaragua directed at each other's violation of the substantive obligations concerning environmental law. But the ICJ dismissed both Parties' claims. The ICJ noted that:

Over the past four years, the Parties have presented to the Court a vast amount of factual and scientific material in support of their respective contentions. They have also submitted numerous reports and studies prepared by experts and consultants commissioned by each of them on questions such as technical standards for road construction; river morphology; sedimentation levels in the San Juan River, their causes and effects; the ecological impact of the construction of the road; and the status of remediation works carried out by Costa Rica. ${ }^{103}$

Then, the Court concluded that the available evidence by both Parties did not convince it. Thus it can be seen that, due caution should be exercised in evaluating the scientific evidence, especially in the maritime and environmental cases. In the present case, if the Tribunal has to decide whether any obligation has been breached, it does not follow those evidence provided unilaterally. The article argues that the Tribunal should pay attention to the method and approach adopted by the ICJ, including how to handle the relation between the arbitrators and the experts, the standards of examination of scientific evidences and other relevant rules. This article concludes that, the fact-finding task of this present complex case is the impossible one for the five Arbitrators.

\section{Conclusion}

The relationship chain of "Evidence-Fact-Law" can be found in all international litigations and arbitrations. Whether "Evidence-Fact" can be established is an issue of fact-finding, whereas the "Fact-Law" relationship chain depends on the prerequisite to the application of the law and it is an issue of law. ${ }^{104}$ Rules

102 Certain Activities carried out by Nicaragua in the Border Area (Costa Rica v. Nicaragua), Judgment, para. 176 .

103 Ibid., paras. 117-120, 175, 203-217.

104 Chen Hangping, On the Distinction between "Question of Fact" and "Question of Law", 134 Peking University Law Journal (2011), pp. 332-336. 
concerning the choice and validity of evidence are essential to solving all legal issues. Although there are differences between inter-State litigation (or arbitration) and domestic litigation (or arbitration), it is recognized that they share many similarities with respect to the rules concerning evidence. International legal practice is more vague than domestic legal practice in this regard, and therefore it suffers from being questioned and challenged to a greater extent. Starting from the analysis of the Jurisdictional Award, this paper fully examines the general issues of fact-finding and the use of evidence in international litigations. Accordingly, it examines several specific issues concerning factfinding and the use of evidence arising from the Award.

First of all, with regard to the source of evidence, it is recognized that in international legal practice, evidence are basically submitted by disputed parties voluntarily. By examining the over seventy years long history of the International Court of Justice, it can be found that most judicial decisions are made by examining evidence submitted by disputed parties and applying legal principles accordingly. Though recently, there are occasions that disputed parties submitted third-party reports or documents as evidence, the ICJ seldom regards these materials as authentic or reliable. ${ }^{105}$ This leads to another issue, that is, the ambiguous authentication of such evidence. In the present Arbitral Award, the Tribunal simply decided that the evidences submitted were "sufficient"106 to validate relevant arguments and it has been convinced of such arguments, without providing convincible elaboration or reasoning.

Secondly, concerning the approach of using the evidence, it can be summarized from the above analysis that the Tribunal failed to consider, mention or even be aware of the existence of those evidence that may possibility lead to a different conclusion. The Tribunal claimed that it only relies upon evidence that can support its conclusion. As a result, the Tribunal intentionally ignored other evidence that may contravene its presupposed conclusion. This kind of situation can be identified at the present jurisdictional stage and may well exist at the merits stage in the foreseeable future.

Thirdly, in the process of evaluating the probative value of various public documents and statements provided by the Philippines, the Tribunal seemed to evaluate the documents and statements in such a way as ignoring their context. In the present arbitration, this article finds that the Tribunal seemed to

105 See Simone Halink, All Thinks Considered: How the International Court of Justice Delegated Its Fact-Assessment to the United Nations in the Armed Activities Case, (2008) $40 \mathrm{NYU}$ J Int'l L \& P, pp. 13-52; A. Mark Weisburd, Failings of the International Court of Justice (Oxford University Press, 2015), pp. 189-192.

106 Award, paras. 219, 285, 333 . 
"split" each document and statement to the effect of supporting the claimant, rather than situating the materials in their historical context.

At last, fraught with far-fetched and unfounded assumptions, the reasoning process of the Tribunal was by no means based on facts, common sense or justice, and its positions were neither fair nor impartial. ${ }^{107}$ The Tribunal deliberately framed the Philippines' evidence in a favorable way, ignored the jurisprudence of other international courts, and thus disregarded of the basic facts. This article concludes that what has truly happened was not found by the Tribunal in the jurisdiction and admissibility Award. It is questionable that this will be found at the merits stage. That being the case, the international judicial system that champions fairness and justice is at a risk of being eroded.

107 People's Daily: Disregarding facts and jurisprudence, arbitration is neither fair nor just, available at the website of Ministry of Foreign Affairs of the People's Republic of China, http://www.fmprc.gov.cn/mfa_eng/topics_665678/nhwt/t1326343.shtml (last visited on 25 April 2016). 